\title{
Effects of the Maize Input Subsidy Program on Groundnuts Production in Zambia
}

\author{
Peter Zulu ${ }^{1}$, Thomson Kalinda ${ }^{1} \&$ Gelson Tembo ${ }^{1}$ \\ ${ }^{1}$ Department of Agricultural Economics \& Extension, University of Zambia, Lusaka, Zambia \\ Correspondence: Thomson Kalinda, Department of Agricultural Economics and Extension, University of Zambia, \\ Lusaka, Zambia. Tel: 260-966-454-366. E-mail: thomsonkalinda@gmail.com
}

\author{
Received: April 15, 2014 Accepted: May 15, 2014 Online Published: June 15, 2014 \\ doi:10.5539/jas.v6n7p253 URL: http://dx.doi.org/10.5539/jas.v6n7p253
}

\begin{abstract}
This study uses a three-wave panel dataset from nationally representative surveys by the Central Statistical Office and Cragg's (1971) model for corner-solution problems to determine the effect of the government-sponsored maize input subsidy program on the production of groundnuts in Zambia. The results show that even though the maize subsidy programme, does not significantly affect the smallholder farmer's decision to participate in groundnuts production, maize subsidies however do significantly influence the proportion of cultivated land area allocated to groundnuts production. This finding confirms that the current high subsidy levels targeted at maize are causing farmers to relocate their productive resources, particularly land, from other cropping enterprises towards maize production. The results also show that land allocation to groundnuts is also influenced by the household's labour endowment, level of activity of the Food Reserve Agency (FRA) in the district, the household's access to market information, and the price of groundnuts relative to prices of other related commodities like maize, mixed beans, cowpeas and soyabeans.
\end{abstract}

Keywords: agricultural household, Cragg's double hurdle, groundnuts, input subsidies, Zambia

\section{Introduction}

Groundnuts are the second widely grown crop by smallholder farmers after maize in Zambia. The crop is mostly grown in Eastern Province, where over 69 percent of the smallholder farmers produce 30 percent of total national production (CSO, 2011). Groundnuts are a major crop used in conservation farming practices like crop rotation and intercropping. In crop rotation, groundnuts are grown on a field intended for production of a cereal crop (mostly maize) in the next season while in intercropping, groundnuts are grown side-by-side with a cereal crop such as maize, sorghum or millet. In both above practices, the cereal crop grown after or side-by-side with groundnuts benefits from the nitrogen that groundnuts fix from the atmosphere, with the potential benefit of cutting down on the need for inorganic fertilizers and their associated water and soil pollution (Shaxson et al., 2008).

For smallholder farm households, groundnuts are not only a major source of protein but they are also a major source of income. Ross and de Klerk (2012) report that about 34\% of the total quantity of groundnuts produced in Zambia are sold mostly on the open market with the remaining $66 \%$ being retained for home consumption. Over the years, the crop has enjoyed an upward production trend by smallholder farmers. Between 2000 and 2011, the crop saw 22 percent, 18 percent and 6 percent increases in area planted, number of farmers growing it, and yield levels, respectively. Ross and de Klerk (2012) estimate growth rates of 2 percent, 1.7 percent and 0.6 percent, respectively. Groundnuts are, however, prone to foliar and underground pests and diseases. Many factors have been identified for the dismal yield growth rates, including heavy weeding labour demands, and low utilization of improved seed. Only 20 percent of the smallholder farmers use improved seed varieties with the remaining 80 percent relying on recycled seed (Ross \& de Klerk, 2012).

Despite its significance in the smallholder farm household farming system and food security, the groundnuts sector has not received any direct government support. One of the major initiatives taken to enhance crop production among Zambian smallholder farmers has been the distribution of subsidized inorganic fertilizers and improved seed mainly for production of maize, which is the major staple crop (Longley et al., 2006; Mason \& Jayne, 2012). The Zambian government introduced the maize input subsidy programs in the 1990s that provided inorganic fertilizer and improved maize seed to smallholder farmers at prices well below open market prices. Although the 
program has taken different forms and names over the years, the up-scaled 2002 Fertilizer Support Programme (FSP) and its successor, the Farmer Input Support Program (FISP), have by far been the most comprehensive. Apart from being subsidized at production, maize is also subsidized at marketing and consumption levels. For example, in 2010, the Food Reserve agency (FRA) was buying maize at pan-territorial prices that are 22-91 percent higher than the cost of production which has made maize production appear artificially more profitable than other crops (Burke et al., 2011). In an attempt to subsidize consumption, FRA has also been selling maize to millers at a price lower than the purchase price. However, research shows that this is not fully passed on to consumers (Mason \& Ricker-Gilbert, 2013).

There is a growing concern that the government sponsored maize input subsidy program could be suppressing the production of other crops such as groundnuts by smallholder farmers, who are the major producers of the crop (Mason et al., 2013). This concern is compounded by the fact that the production of both maize and groundnuts compete for productive resources. Thus farmers are likely to shift resources like land and labour from groundnuts production to maize because of the support that maize receives at production and marketing, which makes it more attractive for farmers to produce. This trend, if left unchecked, could lead to a maize mono-cropping system of agriculture, which would accelerate the problem of soil degradation through the use of marginal lands that would otherwise not be used for crop production. The trend could also lead to increased levels of malnutrition among the smallholder farm households as meat, the other source of protein, is either not available or beyond the reach of most households.

The issues highlighted above call for a need to fully understand the effect or impact of Zambia's maize input subsidy program on the production of major crops like groundnuts and others. Coeb (2011) found that although government maize output price support through the FRA had a positive and significant impact on cotton production, FISP had no significant impact on either the farmers decision to produce cotton or how much land to allocate to cotton production. Furthermore and Ricker-Gilbert (2011) and Xu (2009) found that government subsidized inputs do crowd out commercial fertilizer and commercial seed purchases despite enhancing total fertilizer and total maize seed use by smallholder farm households. None of these earlier efforts measure the effect of maize input subsidies on resource allocation to competing crops like groundnuts.

This study uses three-wave panel data from nationally representative surveys to determine the effect of the government-sponsored maize input subsidy program on the production of groundnuts among smallholder farmers in Zambia. The rest of the paper is organized as follows. The conceptual framework is presented in section 2, followed by methodology in section 3. Results and discussion, and conclusions are presented in sections 4 and 5 , respectively.

\section{Conceptual Framework}

This study follows or uses both the conceptual and empirical frameworks used by Takeshima et al. (2013) and Ricker-Gilbert et al. (2011), which focus on the effect of subsidised inputs on other agricultural policies. In a perfectly competitive market environment, the forces of demand and supply exogenously determine market prices for agricultural inputs and outputs and form a basis for household consumption and production decisions (Takeshima et al., 2013). In addition, household consumption and production decisions are influenced by demographic and household-specific characteristics and constrained by household resource endowment (Sadoulet \& de Janvry, 1995).

In an African rural setup, the assumption of separability is not likely to hold since markets are very thin thus limiting farmer access to input and output markets (Takeshima et al., 2013). This implies that farmer choices can be modelled as a constrained utility maximisation problem (Singh et al., 1986). Thus the resultant utility maximisation problem can be presented as:

$$
\operatorname{Max}_{c} U\left(c, \mathbf{h}^{S}\right),
$$

subject to income, credit, asset endowment, production technology, prices and equilibrium conditions for tradables (Takeshima et al., 2013). Here, c represents consumables while $\mathbf{h}^{\mathrm{s}}$ is a vector of household characteristics such as landholding, age, gender and education level of household head and location. Sadoulet and de Janvry (1995) observe that the reduced form to this constrained utility maximisation problem does not only depend on prices but also on household characteristics and yields reduced form specifications of demand for inputs and technologies and supply of outputs. Thus the demand for inputs $i$ can me expressed as (Takeshima et al., 2013):

$$
q_{i}=q\left(p_{i}^{*}, \mathbf{h}^{s q}\right) \text {. }
$$

Here, $q_{i}<0$ since we are dealing with fertilizer, which is an input. $\mathbf{h}^{\text {sq }}$ represents household characteristics associated with household demand for input $i$ (subsidized fertilizer) while $\mathrm{p}^{*}$ represents prices (exogenous) for 
required inputs. It is expected that the price of fertilizer will fall due to the presence of input subsidies resulting in increased demand. Consequently, it is expected that the supply of maize, which is the target crop for the subsidies, will increase leading to a fall in the price of maize grain and its products. Farmers' productive capacity is constrained by resource endowment including land holding and productive assets, which they have to rationally allocate to maximise returns. Thus in the face of maize subsidies, it is expected that farmers will shift these resources from production of groundnuts to maize production resulting in a net reduction in groundnuts production. This is because groundnuts production competes with maize production for productive resources.

However, conditions could arise that may hinder the above outcome to materialize. First, if market prices for groundnuts rise to levels where they more than compensate for subsidies received by maize, farmers may instead increase the production of groundnuts to maximise returns. Second, if recipients of input subsidies direct some of the fertilizer (especially D-compound) towards groundnuts production, production of both maize and groundnuts would increase. Both these scenarios would result in a distortion of our expected results.

Thus the study required that we control for possible fertilizer endogeneity and differences in fertilizer response. The control function approach was used to control for possible fertilizer endogeneity while provincial dummy variables were employed to control for differences in fertilizer responses due to location differences.

Amede (2003) points out that farmer's decision to incorporate a legume in their farming system is influenced by food habits, land productivity, farm size, land tenure, access to input and output markets and livestock ownership. Mustapha et al. (2012) further identifies education level of head, experience in farming, access to credit, and contact with extension officer, access to information and distance to market as major factors that affect groundnuts production. Consequently, the groundnuts production function can be presented as:

$$
L G=f(\mathbf{F}, \mathbf{C}, \mathbf{G}, \mathbf{D}, \mathbf{I}, \mathbf{S}, \mathbf{P})
$$

In this model, $L G$ represents area of field under groundnuts by a household (in hectares) which is affected by the amount of subsidized inputs a household receives (F), the price of commercial inputs $(\mathbf{C})$ and the market prices of agricultural goods (G). Groundnuts production is further likely to be affected by exogenous factors like household location and distance to input and product markets which are represented by $\mathbf{D}$. Household socio-demographic factors like gender, education levels of household head, are also likely to affect the farmers decision to produce groundnuts and how much groundnuts to produce and are represented by $\mathbf{S}$ while asset endowment and household labour size are represented by $\mathbf{I}$. Other factors directly or indirectly likely to effect the farmers' decision to produce groundnuts such as public and private service provisions are represented by $\mathbf{P}$ (Marenya $\&$ Barrett, 2007).

\section{Methodology}

\subsection{Empirical Model}

We operationalize the conceptual model in (3) as follows (Wooldridge, 2002):

$$
\begin{aligned}
& L G_{i t}=\beta_{0}+\beta_{1} F_{i t}+\boldsymbol{\beta}_{2} \mathbf{X}_{i t}+\varepsilon_{i t} \\
& \varepsilon_{i t}=c_{i}+\mu_{i t},
\end{aligned}
$$

where $L G_{i t}$ is land area under groundnuts (in Hectares) by farmer $i$ at period $t$ and $\beta_{0}$ is a parameter to be estimated. $F_{i t}$ represents our key variable of interest, quantity of subsidised fertilizer received by farmer $i$ in period $t$ while $\mathbf{X}_{i t}$ represents the other explanatory variables assumed to affect groundnuts production by farmers with $\beta_{1}$ and $\boldsymbol{\beta}_{2}$ being parameters to be estimated. $\boldsymbol{X}$ includes socio-demographic factors like household labour size (represented by number of adult equivalents), age, sex and education level of the household head. Other factors included in $\mathbf{X}$ are farm asset endowment like landholding size and livestock ownership. $\mathbf{X}$ also includes price of fertilizer at planting time, naïve prices of maize and groundnuts, farmers' access to market and production information, whether the farmer practices conservation farming and provincial and year dummy variables. In this model, the error term $\varepsilon_{i t}$ has two parts; the unobserved time-constant variables represented by $\mathrm{c}_{i}$ and the unobserved time-varying variables, $\mu_{i t}$. Included in $\mathrm{c}_{i}$ are variables like soil fertility while $\mu_{i t}$ includes variables like political environment.

\subsection{Controlling for Unobserved Heterogeneity and Endogeneity}

Like in many Sub-Saharan African countries, not all smallholder farm households grow groundnuts. This means that our dependent variable, area of land under groundnuts production, will take on properties of nonlinear corner solution variables. Generally, independence of covariates from unobserved heterogeneity, $c_{i}$, is a prerequisite to obtaining efficient estimates under the random effects framework (Ricker-Gilbert et al., 2011). If this assumption is violated, the random effects estimator becomes inconsistent. Traditionally, fear for this latter condition forced 
analysts to always use the fixed effects (FE) estimator, which is consistent regardless whether or not the independence assumption holds. However, the FE framework does not lend itself to estimating the parameters of time-constant variables, which renders it useless if such variables are of interest to the researcher. The limitations of the FE frameworks can be relaxed by employing the correlated random effects (CRE) or the Mundlak-Chamberlain device (Wooldridge, 2010). CRE requires the following assumptions about $c_{i}$;

$$
\begin{aligned}
& c_{i}=\psi+\bar{x}_{i} \xi+a_{i} \\
& \text { where } a_{i} \mid x_{i} \sim \operatorname{Normal}\left(0, \sigma^{2}\right)
\end{aligned}
$$

where $\bar{x}_{i}$ are time-averages of the time-varying variables. Thus, the CRE framework entails that time-averages of the time-varying variables, $\bar{x}_{i}$, be added to the regression model (Wooldridge, 2010). Apart from controlling for time-constant unobserved heterogeneity, $\mathrm{CRE}$ also allows measurement of effects of time-constant independent variables in the regression model (Ricker-Gilbert et al., 2011).

One of the problems with the input subsidy program is the fact that access to subsidized fertilizer is not random and is likely to be influenced by the poverty targeting objectives of the program (Ricker-Gilbert et al., 2011). This introduces the problem of self-selection bias or endogeneity. In fact, those who decide to participate in the program are subjected to a selection process by Camp Agricultural Committees (CACs) and cooperatives, using unobservable household characteristics (MACO, 2011). The cooperatives are themselves subjected to a selection process by District Agricultural Committees (DACs). There will thus be need to control for these unobservables. An appropriate instrument to help control for this problem is the Control Function (CF) approach. This means taking the residuals from the reduced form model of subsidised fertilizer allocation and including them in our structural model of groundnuts production as covariates and using appropriate instrumental variables (IVs) like the amount of maize (in metric tonnes) purchased by FRA in the district (Ricker-Gilbert et al., 2011). This IV is appropriate for our estimation as it is not directly correlated with other time-varying factors in the error term in our model for groundnuts production by smallholder farm households. We will thus assume that this IV is exogenous and uncorrelated with other covariates in our model (Ricker-Gilbert et al., 2011).

That is, we test and control for endogeneity by first regressing the suspected endogenous variable (Kgs of subsidised fertilizer received by the household) on the rest of the explanatory variables of our model in equation 3 . Included among the explanatory variables was the instrumental variable (IV) 'FRA maize purchase in the district' (Wooldridge, 2010). A CRE reduced form Tobit was employed for this purpose. With a p-value $<0.001$, we reject the null hypothesis that government subsidised fertilizer is exogenous. Thus, both the IV and the computed generalised residues from the reduced form model were included as regressors in the main regression. The resultant APEs from this regression were then bootstrapped 500 times to obtain robust standard errors which were used in interpreting the results (Wooldridge, 2010). We use Stata to implement all the models and Microsoft Excel for further results manipulations and graphing.

\subsection{Attrition Bias}

Use of rotational panel like our data introduces two kinds of attrition bias (Wooldridge, 2002). The first attrition occurs when some households that were interviewed in the first or second wave drop out in the subsequent survey. In rotational panel, such households are replaced by new ones. In our data, of the 6,922 smallholder farm households interviewed in the first wave (1999/2000), 5,358 were re-interviewed in the second wave (2003/04) while 4,286 were successfully re-interviewed in the third wave (2007/08). Thus, we use a balanced panel of 4,286 households in our data analysis by eliminating those households that did not participate in all the three waves. The second form of attrition occurred when some respondent who grew groundnuts in the first or second waves stop growing the crop in subsequent seasons. This is called incidental truncation problem and was controlled for using the correlated random effect (CRE) or the Mundlak-Chamberlain device (Wooldridge, 2010) as specified in equation (5) above.

\subsection{Model Selection}

Not all farmers allocate land to groundnuts production, leading to results pilling-up at zero for the dependent variable. In such situations, where the dependent variable is a continuous positive random variable but with many zeros, ordinary least square methods of analysis are inconsistent (Yimer, 2011; Green, 2007). Censured regression models like Tobit and the hurdle models are specially designed to deal with such situations (Wooldridge, 2002).

In general, the standard Tobit model is specified as:

$$
h_{i}^{*}=\mathbf{x}_{i}^{\prime} \text { ot } \varepsilon_{i} \text { with } \varepsilon_{i} \sim N\left(0, \sigma^{2}\right) \text { and } i=1, \ldots, n
$$




$$
h_{i}=\left\{\begin{array}{l}
h_{i}^{*} \text { if } h_{i}^{*}>0 \\
0 \text { if } h_{i}^{*} \leq 0,
\end{array}\right.
$$

where $h_{i}^{*}$ represents the individual's desired level of groundnuts production with $h_{i}$ representing its corresponding actual level of production. Individual characteristics that explain both participation and level of participation are represented by $\mathbf{X}_{i}$ with $\boldsymbol{\beta}$ representing a corresponding vector of parameters to be estimated. Equation (7) implies that the observed levels of production are positively continuous if only positive land area under groundnuts production is desired, and zero otherwise. Since area can never be negative, the censoring could be placed at zero without loss of generality (Wodjao, 2007). Thus the observed zeros on $h_{i}$ imply either an individual's deliberate choice (true zero) or those caused by data collection methods (censured zero) (Yen \& Jensen, 1995; Wodjao, 2007). Here $\varepsilon_{i}$ is assumed to be a homoscedastic and normally distributed error term (Wodjao, 2007).

One of the major limitations of the Tobit model is its assumption that the same set of parameters and variables determine both the probability of participation and levels of participation (Wodjao, 2007; Yen \& Jensen 1995). This is in addition to the model producing biased and inconsistent parameter estimates in the face of heteroskedasticity or normally distributed errors in limited dependent variable models (Yen \& Jensen, 1995). Due to these inadequacies of the Tobit model, Cragg suggested the double hurdle model (Cragg, 1971; Zhang et al., 2006). In the double hurdle model, a farmer is expected to overcome two hurdles in order to successfully produce groundnuts (Wodjao, 2007; McDowell, 2003). Thus, the double hurdle model allows for separation of the decision process to successfully produce groundnuts into two stages (Wooldridge, 2002). In this study, it is assumed that the farmer will first have to make a decision to participate in groundnuts production. This decision would most likely be made well before planting time. This is followed by the second decision as to how much of the groundnuts to produce. This will probably be made at planting time depending on resource availability. The double hurdle model assumes that these two decisions are independent, observable and unique (Ricker-Gilbert et al., 2011; Jones, 1992). The standard Tobit Model is thus modified to accommodate this development. For our purposes, the model would be defined as (Wodjao, 2007; Aristei \& Pieroni, 2007; Newman et al., 2003):

$$
h_{i}=\left\{\begin{array}{l}
h_{i}^{*} \text { if } p_{i}=1 \text { and } h_{i}^{*}>0 \\
0 \text { otherwise, }
\end{array}\right.
$$

where $p_{i}$ is the observed value of the individuals participation decision which assumes the value 1 if respondent reports positive area of groundnuts grown and 0 if not (Wodjao, 2007)). Unlike in the standard Tobit model, $h_{i}$ in equation (8) is zero either when there is censoring at zero $\left(h_{i}^{*} \leq 0\right)$ or if there is faulty reporting or as a result of random circumstances (Wodjao, 2007; Wooldridge, 2010). However, this assumption could also fail. For example, let us assume that a farmer is randomly selected to participate in a drive to promote groundnuts production. This means that the farmer's decision to produce groundnuts and how much to produce will both be functions of his participation in the promotional program.

The likelihood function for the double-hurdle model has been defined by Gao et al. (1995) as:

$$
L=\prod_{y_{i}=0}\left[1-\Phi\left(x_{1 i} \alpha\right)\right] \cdot \prod_{y_{i}>0} \Phi\left(x_{1 i} \alpha\right)\left[\Phi\left(x_{2 i} \beta / \sigma\right)\right]^{-1} \cdot \frac{1}{\sigma} \cdot \phi\left[y_{i}-x_{2 i} \beta / \sigma\right]
$$

where ' $y_{i}=0$ ' is summation over zero observations and ' $y_{i}>0$ ' representing summation over positive observations. In this equation, $\Phi($.$) represents the standard normal cumulative density function (cdf) with \phi($.$) representing$ standard normal probability density function (pdf) for normal distribution (Goeb, 2011). Equation (9) includes likelihood functions for both probit and truncated regressions, with truncation at zero. A close examination of (9) reveals that Cragg's likelihood function reduces to Tobit's likelihood function when $x_{1 i} x_{2 i}$ and $\alpha=\beta / \sigma$ implying that the Tobit model is nested within Cragg's model (Yimer, 2011).

\subsection{Data and Data Sources}

This study used secondary data from the 2001, 2004 and 2008 national-wide supplemental surveys to the 1999/2000 Post Harvest Survey (PHS) of agricultural households. The surveys were conducted by the Central Statistical Office (CSO) and the Ministry of Agricultural and Livestock (MAL) in collaboration with Michigan State University (MSU) through the Food Security Research Project (FSRP) and covered the 1999/2000, 2002/2003 and 2006/2007 agricultural seasons. The data were collected using a questionnaire that was administered to each pre-selected household. A total of 6,922, 5,419 and 8,094 households were successfully 
interviewed in the 2001, 2004 and 2008 surveys, respectively. A balanced panel data set of 4,286 households that were successfully interviewed in all the three waves was used in this study. These surveys collected information on several aspects of agricultural households, including household characteristics, cropping patterns and systems, livestock rearing, input usage, labour availability, yield levels and output marketing information.

The surveys were carried out in 70 districts and all the 162 Census Supervisory Areas (CSAs). Each CSA nests a number of Standard Enumeration Areas (SEAs), the smallest geographical unit used as the primary sampling unit in CSO surveys and censuses. The results of the 2000 Census of Population and Housing were used to derive the sampling frame for SEAs. Some SEAs were dropped due to the problem of accessibility. A two-stage sampling procedure was employed taking into account the geographical distribution of the SEAs. The first stage involved the use of Probability Proportional to Size (PPS) to draw a sample of 407 rural SEAs from a total of 12,789 SEAs in the sampling frame. In the second stage, all agricultural households in the selected SEAs were listed and categorised into three strata based on the area under crop production, quantities of each crop and livestock and sources of income. Systematic random sampling was then used to select 20 agricultural households from each SEA. In the 2001 and 2004 surveys, non-revisited households were not replaced. However, in the 2008 survey, such households were replaced to ensure that exactly 20 households were interviewed in each SEA. Household specific data like name of household head and household identification numbers were used to ensure easy identification of the exact household during the subsequent surveys (CSO, 2001, 2004, 2008).

The use of the three-wave panel data enabled the study to take advantage of the many benefits that panel data offers. Among the major benefits is the fact that panel data tends to be more informative, has more variability, has less collinearity, has more degrees of freedom (which makes the estimates more efficient), allows for in-depth study of individual dynamics such as separating age and cohort effect, reveals information on the time-ordering of events, and allows for the control of individual unobserved heterogeneity, which is a major problem in non-experimental approaches like this study (Brüderl, 2005). In addition, the use of panel data permits the researcher to control for both observable and unobservable household characteristics.

\subsection{Data Processing and Analysis}

Excel, Statistical Packages for Social Sciences (SPSS) and Statistical Analysis (STATA) computer programmes were employed to analyse and process the data. Excel was mainly used in generating graphs and basic calculations and conversions while SPSS was used to generate summary statistics and cross tabulations. STATA was employed in all the regressions reported in this report.

\section{Results and Discussion}

\subsection{Descriptive Statistics}

Table 1 presents the socio-economic characteristics of sample households. The data shows that about $39 \%$ of the total number of households grew groundnuts with the majority being male headed $(77.85 \%)$. However, there were proportionally more females among groundnuts growing households than non-groundnuts growing households.

Table 1. Social-economics characteristics of the sample households

\begin{tabular}{|c|c|c|c|c|c|c|c|}
\hline \multirow{2}{*}{ Variables } & \multicolumn{2}{|l|}{ Sample } & \multicolumn{2}{|c|}{ Groundnuts growers } & \multicolumn{3}{|c|}{ Non-Groundnuts growers } \\
\hline & Mean & $\%$ & Mean & $\%$ & Mean & $\%$ & p-values \\
\hline Number of farmer & & 100 & & 39.79 & & 60.21 & \\
\hline $\mathrm{Kg}$ of subsidised inputs received & 37.340 & & 53.920 & & 26.390 & & 0.00 \\
\hline Adult equivalent (household labour force) & 5.140 & & 5.400 & & 4.930 & & 0.00 \\
\hline Education level of household head (years) & 5.170 & & 5.330 & & 5.050 & & 0.00 \\
\hline Age of household head (years) & 49.600 & & 50.820 & & 48.890 & & 0.00 \\
\hline Female headed house hold & & 21.820 & & 22.146 & & 21.596 & 0.44 \\
\hline Household landholding size (Ha) & 2.510 & & 3.250 & & 2.020 & & 0.00 \\
\hline Cropped land & 1.910 & & 2.490 & & 1.450 & & 0.00 \\
\hline Access to market information & & 50.004 & & 54.40 & & 39.40 & \\
\hline Livestock ownership & & 80.000 & & 88.800 & & 74.412 & \\
\hline Practice of conservation farming & & 64.248 & & 71.638 & & 59.377 & \\
\hline
\end{tabular}

Source: Own calculation from research data. 
Groundnuts growing households also had a significantly higher average household-labour force at 5.4 compared to 4.9 for non- groundnuts growers with significantly older and more educated household heads. Groundnuts growing households also received significantly more subsidised fertiliser and own and cultivate significantly more land than their non-groundnuts growing counterparts. The data further shows that proportionally more groundnuts-growing households had access to market information and proportionally more of them practice one form or another of conservation farming.

Table 2. Factors affecting probability of participation in groundnuts production and level of participation

\begin{tabular}{|c|c|c|c|c|c|c|}
\hline \multirow{4}{*}{ Independent Variables } & \multicolumn{6}{|c|}{ Proportion of cultivated land allocated to groundnuts production (ha) } \\
\hline & \multicolumn{2}{|l|}{1} & \multicolumn{2}{|l|}{2} & \multicolumn{2}{|l|}{3} \\
\hline & \multicolumn{2}{|c|}{ Unconditional Estimates } & \multicolumn{2}{|c|}{ Probit Estimates } & \multicolumn{2}{|c|}{ Truncated Estimates } \\
\hline & $\begin{array}{l}\text { Average } \\
\text { Partial Effect } \\
(\mathrm{APE})\end{array}$ & $\begin{array}{l}\text { Robust Std. } \\
\text { Error }\end{array}$ & $\begin{array}{l}\text { Average } \\
\text { Partial Effect } \\
(\mathrm{APE})\end{array}$ & $\begin{array}{l}\text { Robust Std. } \\
\text { Error }\end{array}$ & $\begin{array}{l}\text { Average } \\
\text { Partial Effect } \\
\text { (APE) }\end{array}$ & $\begin{array}{l}\text { Robust } \\
\text { Std. Error }\end{array}$ \\
\hline $\begin{array}{l}\text { Quantity of subsidised fertilizer received } \\
\text { (kg) }\end{array}$ & $-1.22 \mathrm{e}-05$ & $9.37 \mathrm{e}-06$ & $2.33 \mathrm{e}-05$ & $3.26 \mathrm{e}-05$ & $-4.26 \mathrm{e}-05^{* *}$ & $1.78 \mathrm{e}-05$ \\
\hline Age of household head (years) & -0.000144 & 0.000310 & 0.000435 & 0.00108 & -0.000582 & 0.000515 \\
\hline $\begin{array}{l}\text { Education level of household head } \\
\text { (years) }\end{array}$ & -0.000235 & 0.00121 & 0.00216 & 0.00438 & -0.00168 & 0.00197 \\
\hline Female headed household (1=yes) & 0.00246 & 0.00349 & 0.00870 & 0.0124 & 0.00180 & 0.00615 \\
\hline $\begin{array}{l}\text { Adult equivalent=household labour } \\
\text { force }\end{array}$ & 0.000625 & 0.00133 & $0.00915^{*}$ & 0.00470 & -0.00303 & 0.00219 \\
\hline Household landholding size (ha) & 0.00204 & 0.00165 & $0.0170 * * *$ & 0.00315 & -0.00344 & 0.00382 \\
\hline Livestock ownership (1=yes) & $0.0176^{* * *}$ & 0.00409 & $0.102 * * *$ & 0.0154 & -0.00839 & 0.00805 \\
\hline Practicing conservation farming ( $1=$ yes) & 0.00639 & 0.00449 & $0.0562 * * *$ & 0.0161 & -0.0127 & 0.00783 \\
\hline Access to market information ( $1=$ yes) & $-0.00960 * * *$ & 0.00327 & 0.00786 & 0.0123 & $-0.0282 * * *$ & 0.00577 \\
\hline $\begin{array}{l}\text { FRA maize purchase in the district } \\
\text { (metric tonnes) }\end{array}$ & $-6.71 \mathrm{e}-05^{* * *}$ & $1.49 \mathrm{e}-05$ & $-0.000271 * * *$ & $5.31 \mathrm{e}-05$ & $-3.26 \mathrm{e}-05$ & $2.40 \mathrm{e}-05$ \\
\hline $\begin{array}{l}\text { Commercial fertilizer price }(\mathrm{ZMK} \\
1,000) \dagger\end{array}$ & $0.00338^{*}$ & $1.85 \mathrm{e}-06$ & $0.0130 *$ & $6.84 \mathrm{e}-06$ & 0.00196 & $3.05 \mathrm{e}-06$ \\
\hline Lagged relative price of maize & $-0.114 * * *$ & 0.0327 & $-0.619 * * *$ & 0.113 & 0.0252 & 0.0564 \\
\hline Lagged relative price of mixed beans & $0.0570 * * *$ & 0.00942 & $0.120 * * *$ & 0.0325 & $0.0833 * * *$ & 0.0179 \\
\hline Lagged relative price of soya beans & $-0.0307 * *$ & 0.0127 & $-0.147 * * *$ & 0.0467 & $-0.151 * * *$ & 0.0206 \\
\hline Year 2004 (dummy) & $0.0996^{* * *}$ & 0.0208 & $0.166^{* * *}$ & 0.0433 & $0.134 * * *$ & 0.0308 \\
\hline Year 2008 (dummy) & $0.0613 * * *$ & 0.0175 & $0.0880 * *$ & 0.0445 & $0.0886^{* * *}$ & 0.0234 \\
\hline Generalised residues from reduced form & $-2.44 \mathrm{e}-05$ & $2.21 \mathrm{e}-05$ & $-9.81 \mathrm{e}-05$ & $8.33 \mathrm{e}-05$ & $-1.21 \mathrm{e}-05$ & $3.75 \mathrm{e}-05$ \\
\hline Number of observations & 12858 & & 12858 & & 5116 & \\
\hline Goodness of fit Chi-square & & & 2365.75 & & 517.63 & \\
\hline Pseudo R-squared & & & 0.164 & & NA & \\
\hline Joint F-test for provincial dummies & & & 96.59 & & 96.59 & \\
\hline
\end{tabular}

Note: $* * *=\mathrm{p}$-value $<0.01, * *=\mathrm{p}$-value $<0.05, *=\mathrm{p}$-value $<0.1$.

$\dagger$ ZMK stands for Zambian Kwacha (currency). 1US\$ was equivalent to 5,450ZMK at time of the study.

Source: Own calculation from research data.

\subsection{Econometric Results}

The results of the Double Hurdle regression are reported in Tables 2. Column 1 represents the unconditional regression APE while column 2 presents results for the probit part. The focus here is on the participation decision (factors that influence the farmers' decision on whether to grow groundnuts or not). Column 3 on the other hand presents results for the truncated normal regression. Here, the focus is on the level of participation, i.e. factors 
affecting the farmers' decision on how much groundnuts to produce, which is here represented by the proportion of land the farmer allocates to groundnuts production.

The results indicate that subsidized maize inputs have a statistically significant effect only on the proportion of cultivated land allocated to groundnut production once the farmer has already decided to grow some. An increase in the quantity of subsidized fertilizer received is associated with a reduction in the proportion of cultivated land area allocated to groundnuts by 0.00004 hectares, ceteris paribus. The results also indicate that maize fertilizer subsidies do not have any statistically significant effects on the decision to get into groundnut production. These results suggest that maize input subsidies are causing farmers to reallocate increasing proportions of their cultivated land from groundnuts to maize production. This is because maize subsidies make maize production appear more attractive to farmers by reducing the cost of production. This is substantiated by the fact that an increase in the commercial price of fertilizer at planting time increases the probability of a farmer growing groundnuts. Both the unconditional and Probit parts show that commercial price of fertilizer during planting time is statistically significant at the participation decision stage. Results show that a ZMK1, 000 increase in the commercial price of fertilizer increases the likelihood of a farmer growing groundnuts by $1.3 \%$.

In addition, both the unconditional and participation results show that relative lagged price of maize, the target crop for the government input subsidy program, significantly, but negatively influence the farmer's decision to grow groundnuts. Results indicate that an increase in the previous season's relative price of maize reduces the likelihood of a farmer to grow groundnuts by $61.9 \%$. These results suggest that the two crops are competitors in relation to land allocation. Thus higher maize prices in the previous marketing season causes the farmer to think of expanding their maize enterprise at the expense of groundnuts.

The results show that although household landholding size is statistically significant on the farmer's decision to participate in groundnuts production, it does not significantly influence the proportion of cultivated land that the farmer allocates to its production. Each additional hectare of land owned increases the probability of a farmer growing groundnuts by $1.7 \%$. Thus having more land enables the farmer to consider growing a wide range of crops including groundnuts, as a way of diversifying their crop enterprises.

Results further indicate that relative price of mixed beans has positive and statistically significant effects on the farmer's decisions to participates in growing groundnuts and how much cultivated land to allocate to the enterprise. An increase in the relative price of mixed beans leads to a12\% increase in the probability of a farmer growing groundnuts while influencing him to increase the proportion of cultivated land allocation to the enterprise by 0.08 Ha. The reason for the apparent complementary relationship between mixed beans and groundnuts production emanates from the fact that the two crops are predominantly produced in different provinces. With a joint provincial dummy F-statistic of 96.59 , results show that there is a statistical difference in the production of groundnuts across the nine provinces of Zambia. National crop production figures show that Eastern Province accounted for $32 \%$ of total land allocated to groundnuts production over the period under consideration. On the other hand, Northern Province accounted for $64 \%$ of the total land allocation to mixed beans production over the same period (Nicholas et al., 2011).

Thus while groundnuts are mainly produced in Eastern Province, mixed beans are predominantly produced in Northern Province. The higher altitude, high rainfall and long rain season in Northern Province (region III) favours bean production as the crop, with its short growing period, can be grown twice in one season while the relatively heavy soils and medium rainfall of Eastern province (region II) favour groundnut production (ZARI, 2009). Thus while farmers in Eastern Province grow groundnuts as a commercial crop, those in Northern Province tend to grow mixed beans instead. This is in addition to the fact that the two crops have two different uses in the nutrition of smallholder households. While beans is consumed directly as a complement to the main carbohydrate diets in most smallholder households in Zambia, groundnuts are either consumed as a snack or processed into powder or cooking oil that are then added to a variety of dishes to improve both taste and nutrition.

Results also indicate that both the decisions to grow groundnuts and how much cultivated land to allocate to groundnuts production are both negatively but statistically influenced by lagged prices of soya beans. An increase in the price of soya beans in the previous marketing season reduces the likelihood of a farmer participating in groundnuts production by $14.7 \%$ while influencing the farmer to reduce area of cultivated land allocated to groundnuts production by $0.15 \mathrm{Ha}$ ceteris paribus. These results highlight the competitive relationship that exists between groundnuts and soyabeans production in the smallholder farm household. Rationally, an increase in the price of soyabeans influences the farmers to plan increasing their soya beans production and resulting in reallocation of production resources, particularly land, from groundnuts to soya beans with the aim of maximising income. This move directly leads to a reduction in allocation of cultivated land to groundnut production. The 
competitive nature of the two crops seems to be more commercially inclined. A closer look at the data shows that the two legumes are the most traded ones by smallholder farm households with $92.76 \%$ and $65.15 \%$ of soya beans and groundnuts growers participating on the market respectively.

FRA maize purchase in the district also has a statistically significant effect on the farmer's initial decision to produce groundnuts and the proportion of land the farmer allocates to groundnuts production. An additional metric tonne of maize purchased by FRA in a district in the previous marketing season reduces the likelihood of the farmer to grow groundnuts by $0.03 \%$ while causing the farmer to reduce proportion of cultivated area allocation to its production by $0.00003 \mathrm{Ha}$. This is because higher maize prices in the previous season imply same or higher prices in the current season to rational farmer. Thus, as expected, farmers reallocate some of their cultivated land from groundnuts production to maize production with the aim of maximising income.

Ironically, a farmer's access to market information on commodity prices have a statistically significant negative effect on the proportion of cultivated land the farmer allocates for production of groundnuts after deciding to grow the crop. Results indicate that farmers with access to market information particularly on commodity prices tend to allocate $0.03 \mathrm{Ha}$ less of their cultivated land to groundnuts production than those who do not. This may imply that the market information being disseminated is focused on crops other than groundnuts. Thus as a precaution, farmers who have access to market information are influenced to reallocate their cultivated land from groundnuts (whose prices they do not know) to the crops that are adequately covered in the market information dissemination programmes.

Livestock ownership has a statistically significant effect on the farmer's decision to grow groundnuts. Farmers who own livestock are generally $10.2 \%$ more likely to grow groundnuts than those that do not. This highlights the fact that farm power is one of the major constraints in crop production among Zambian smallholder farm households. This is especially so with labour intensive crops like groundnuts (Okumu, 1998; Van De Burg, 2012; Govindaraj \& Mishra, 2011). It therefore follows that livestock ownership, especially oxen, increases the probability of a farmer to grow groundnuts as this avails him with more farm power than those that do not own livestock. Farmers with livestock are also able to quickly raise money for labour through the sale of livestock. Sometimes, these farmers actually barter meat from their livestock for labour thus availing them excess labour that enables them to cultivate bigger fields to accommodate increased crop production. This is supported by the fact that households with more household labour are $0.9 \%$ more likely to venture into groundnuts production.

Farmers that practice conservation farming methods are also likely to allocate proportionately more cultivated land to groundnuts production. Results show that such farmers are 5.6\% more likely to produce groundnuts than those that use conventional methods. This is probably because conservation farming practices (crop rotation, improved fallow and intercropping) entails the growing of a legume either in rotation or side-by-side with a serial crop (Nel \& Loubser, 2004). In this way, the cereal crop benefits from the atmospheric nitrogen fixed by the rhizobium bacteria hosted by the roots of the leguminous plant. Thus in Zambia, where maize (the target crop for subsidies) is the major serial crop and groundnuts the major legume crop grown by smallholder farm households, the two crops are the main crops grown by farmers practicing conservation agriculture.

\section{Conclusion and Recommendations}

\subsection{Conclusion}

Econometric results show that although maize subsidies do not significantly affect the farmers' decision to participate in groundnuts production, they do negatively influence the proportion of total cultivated land the famer allocates to groundnuts production. These results are a confirmation of stakeholder concern that the current high maize subsidy levels are causing farmers to relocate their productive resources, particularly land from the production of other equally important crops like groundnuts to maize production in an effort to maximise returns in the face of a limited resource base. Thus farmers appear to be allocating increasingly more cultivated land to maize production at the expense of groundnuts production. This defeats the diversification policy that the government is pursuing.

Notable factors that positively affect the farmers' decision to participate in groundnuts production include productive factors like household landholding and livestock ownership and practicing conservation agriculture which all enables the smallholder farm household overcome production constraints like lack of land and farm power. As expected, maize price in the previous marketing season negatively affects the farmers' decision to produce groundnuts.

Apart from quantity of subsidised fertilizer received by a household, the farmers' decision on the proportion of total cultivated land to allocate to groundnuts production is mostly influenced by economic factors like own price 
and prices of related commodities like maize, mixed beans, soyabeans and cowpeas. The level of FRA activities in the district, household labour size and access to market information also seem to influence the farmers' decision on the proportion of land the farmers allocates to groundnuts production. These results highlight the fact that economic factors like own price, prices of related crops and agricultural inputs are among the most important factors that the farmer considers when deciding to grow various crops and allocating his cultivated land to various crops. Thus the crop that is likely to bring the highest return on resources is likely to be allocated more resources.

\subsection{Recommendations}

Side-by-side with the maize input subsidy policy, the government of Zambia has been promoting the crop diversification policy. This is with the realisation that currently the country's crop production system is rain-fed. This makes the sector very susceptible to changes in weather pattern in the face of climate change. The findings of this study should serve as a means of re-aligning the government supported maize input subsidy programme with a view to lessen or avoid its adverse effects on the production of other equally important crops like groundnuts. This can be done by introducing groundnuts in the subsidised input pack with consideration to its regional suitability. For example, input packs distributed to farmers in Eastern province where groundnuts production is high should include certified groundnuts seed. An introduction of the e-voucher system would ensure smooth implementation through an improvement in farmer targeting as well as availing farmers an opportunity to obtain inputs of their choice. Groundnuts production should also be given a "pull" through provision of market support. Considering the importance of groundnuts in national and household food security, this support can best be done by including groundnuts in the range of crops bought by FRA which is in line with its mandates of "administering a national strategic food reserve" and "marketing and market facilitation" FRA (2013). In addition, government can help trigger the participation of private buyers and processors in marketing of legumes. The processors would require capacity building in terms of training and equipment to enhance their capacity to effectively perform their role. This should go side-by-side with enhancing dissemination of market information along the groundnuts value chains to enable actors make prompt and informed decisions.

\section{Acknowledgements}

The authors would like to thank staff and management at Indaba Agricultural Policy and Research Institute (IAPRI) for availing the data used in this study. The contribution of Nicole Mason for her input on an appropriate methodology to adequately address the objectives of this study is greatly appreciated.

\section{References}

Amede, T. (2003). Pathway for fitting legumes into the farming system of East African highlands: A dual approach. CIMMYT, Zimbabwe. http://dx.doi.org/10.2307/1909582

Aristei, D., \& Pieroni, L. (2008). A double-hurdle approach to modelling tobacco consumption in Italy. Applied Economics. Retrieved from http://www.tandfonline.com/doi/abs/10.1080/00036840600970229

Brüderl, J. (2005). Panel Data Analysis. Retrieved from http://www2.sowi.uni-mannheim.de/lsssm/veranst /Panelanalyse.pdf

Burke, J. W., Hichaambwa, M., Banda, D., \& Jayne, T. S. (2011). The cost of maize production by smallholder farmers in Zambia. Food Security Research Project Working Paper No. 50. Lusaka, Zambia. Retrieved from http://www.iapri.org.zm/index.php/research-reports/working-papers

Burke, J. W., Jayne, T. S., \& Chapoto, A. (2010). Factors contributing to Zambia's 2010 maize bumper harvest. Indaba Agricultural Policy Research Institute Working Paper No. 48. Lusaka, Zambia. Retrieved from http://www.iapri.org.zm/index.php/research-reports/working-papers

Cragg, J. (1971). Some statistical models for limited dependent variables with application to the demand for durable goods. Econometrica, 39, 829-44.

CSO. (2011). Living Conditions Monitoring Survey Report 2006 and 2010. GRZ, Lusaka, Zambia. Retrieved from http://www.zamstats.gov.zm/report/Lcms/2006-2010\%20LCMS\%20Report\%20Final\%20Output.pdf

CSO/MACO/FSRP. (2001, 2004, 2008). Supplemental Surveys to the 1999/2000 Post-Harvest Surveys Data Sets. Lusaka, Zambia

FRA. (2013). Food Reserve Agency “About Us”. Retrieved October 15, 2013, from http://www. fra.org.zm

Gao, X. M., Wailes, J. E., \& Cramer, L. (1995). Double-hurdle model with bivariate normal errors: An application to U.S. rice demand. Journal of Agricultural and Applied Economics, 27, 363-376. Retrieved from http://purl.umn.edu/15273 
Goeb, J. C. (2011). Impact of government maize support on smallholder cotton production in Zambia. A thesis submitted to Michigan State University, Michigan, USA. Retrieved from http://fsg.afre.msu.edu/zambia/goeb_ms.pdf

Govindaraj, G., \& Mishra, A. P. (2011). Labour demand and labour saving options: A case of groundnut crop in India. Agricultural Economics Research Review, 24, 423-428. Retrieved from http://purl.umn.edu/119394

Greene, H. W. (2007). Econometric Analysis (6th ed.) Prentice Hall, Upper Saddle River, NJ 07458.

Jones, A. M. (1992). A note on computation of the double-hurdle model with dependence with an application to tobacco expenditure. Bulletin of Economic Research, 44, 67-74. http://dx.doi.org/10.1111/j.1467-8586.1992.tb00507.x

Longley, C., Kachule, R., Madola, M., Maposse, I., Araujo, B., Kalinda, T., \& Sikwibele, H. (2006). Agricultural input vouchers in Southern Africa: Synthesis of research findings from Malawi, Mozambique and Zambia. FANRPAN. Pretoria, RSA. Retrieved from http://www.fanrpan.org/documents/d00236/

MACO. (2011). Farmer Input Support Programme implementation manual 2011/2012 Agricultural Season. MACO, Lusaka, Zambia.

Marenya P, P., \& Barrett, B. (2007). Household-level determinants of adoption of improved natural resources management practices among smallholder farmers In Western Kenya. Food Policy, 32, 515-536. http://dx.doi.org/10.1016/j.foodpol.2006.10.002

Mason, M. N., Jayne, T. S., \& Mofya-Mukuka, R. (2013). Zambia's input subsidy programs. Agricultural Economics, 44, 1-16.http://dx.doi.org/10.1111/agec.12077

Mason, N. M., \& Jayne, T. S. (2012). Fertilizer subsidies and smallholder commercial fertilizer purchases: Crowding out, leakages and policy implication for Zambia. IAPRI Working Paper No.70. Lusaka, Zambia. Retrieved from http://www.iapri.org.zm/index.php/research-reports/working-papers

Mason, N. M., \& Ricker-Gilbert, J. (2013). Disrupting demand for commercial seed: Input subsidies in Malawi and Zambia. World Development, 45, 75-91. http://dx.doi.org/10.1016/j.worlddev.2012.11.006

McDowell, A. (2003). From the help desk: hurdle models. The Stata Journal, 3, 178-184.

Mustapha, S. B., Makinta, A. A., Zongoma, B. A., \& Iwan, A. S. (2012). Socio-economic factors affecting adoption of soya bean production technologies in Takum Local Government area of Taraba State, Nigeria. Asian Journal Agriculture and Rural Development, 2, 271-276. Retrieved from http://www.aessweb.com/download.php?id=1353

Nel, A. A., \& Loubser, H. L. (2004). The impact of crop rotation on profitability and production risks in the Eastern and North-Western Free State. Agrekom, 43, 101-111. Retrieved from http://purl.umn.edu/9470

Newman, C., Henchion, M., \& Matthews, A. (2003). A double-hurdle model of Irish household expenditure on prepared meals. Applied Economics, 35, 1051-1061. http://dx.doi.org/10.1080/0003684032000079170

Nicholas J. S., Chapoto, A., Kabwe, S., Tembo, S., Hichaambwa, M., Lubinda, R., ... Nthani, D. (2011). Technical compendium: Descriptive agricultural statistics and analysis for Zambia in support of the USAID mission's Feed the Future Strategic Review. Working paper No. 52, Food security Research Project. Lusaka. Zambia. Retrieved from http://www.iapri.org.zm/index.php/research-reports/working-papers

Okumu, M. O. (1998). Economic evaluation of groundnuts as an alternative cash crop for smallholder farmers in Matunda Trans-Nzoia District. Ministry of Agriculture and Rural Development, Kitale, Kenya. Retrieved from http://www.kari.org/fileadmin/publications/legume_project/legume2conf_2000/41.pdf

Ricker-Gilbert, J., Jayne, T. S., \& Chirwa, E. (2011). Subsidies and crowding out: double-hurdle model of fertilizer demand in Malawi. American Journal of Agricultural Economics, 93, 26-42. Retrieved from http://hdl.handle.net/10.1093/ajae/aaq122

Ross, S., \& De Klerk, M. (2012). Groundnuts value chain and marketing assessment in Eastern Province, Zambia. Conservation Farming Unit, Lusaka, Zambia.

Sadoulet E., \& de Janvry, A. (1995). Quantitative Development Policy Analysis. The Johns Hopkins University Press, Baltimore and London.

Shaxson, F., Kassam, A., Friedrick, T., Boddey, B., \& Adekunle, A. (2008). Understanding conservation Agricultures' benefits: The roots of soil health and function. A paper presented at the FAO Health Workshop, Rome. Italy. 
Sheskin D. J. (2007). Handbook of parametric and nonparametric statistical procedures (4th ed.). London: Chapman \& Hall/CRC Taylor \& Francis Group Boca Raton.

Singh, I., Square, L., \& Strauss, J. (1986). Agricultural Household Models: Extension, Application and Policy. World Bank, The John Hopkins University Press, Baltimore and London

Takeshima, H., Saweda, L., \& Liverpool-Tasie, O. (2013). Fertilizer subsidy political influence and local food prices in Sub-Saharan Africa: Evidence from Nigeria. A paper prepared for presentation at the 2013 AAEA/CAES joint annual meeting, 4-6 August, 2013. Washington D. C.

Van Der Burg, G. (2012). New horizon for South-African groundnut industry. Bureau for Food and Agricultural Policy. South Africa. Retrieved May 23, 2013, from http:// www.bfap.co.za

Wodjao T. B. (2007). A double-hurdle model of computer and internet use in American households. Department of Economics, Western Michigan University.

Wooldridge, J. M. (2002). Econometric Analysis of Cross Section and Panel Data. Cambridge, MA: The MIT Press.

Wooldridge, J. M. (2010). Correlated Random Effects Models with Unbalanced Panels. Department of Economics. Michigan State University, USA.

World Bank. (2008). Agriculture for Development. World Development Report 2008. The World Bank, Washington D. C.

Xu, Z., Burke, W. J., Jayne, T. S., \& Govereh, J. (2009). Do input subsidy programs "crowd in" or "crowd out" commercial market development? Modeling fertilizer demand in a two-channel marketing system. Agricultural Economics, 40, 79-94. http://dx.doi.org/10.1111/j.1574-0862.2008.00361.x

Yen T. S., \& Huang, C. L. (1996). Household demand for finfish: A generalized double- hurdle model. Journal of Agricultural and Resource Economics, 21, 220-234

Yen, S. T., \& Jensen H. H. (1995). Modelling consumption with limited dependent variables: Application to pork and cheese. Dietary assessment research series report No. 3. Iowa State University. Retrieved from http://www.card.iastate.edu/publications/DBS/PDFFiles/95sr76.pdf

Yimer S. (2011). Determinants of food consumption expenditure in Ethiopia. International Journal of Economic Research, 2, 151-165.

ZARI/JICA. (2009). Growing beans in Zambia: Seed multiplication. FoDiS information series manual for farmers. Mount Makulu Research Station, Chilanga, Zambia.

Zhang, F., Huang, C. L., \& Lin, H. B. (2006). Modelling fresh organic produce consumption: A generalised double-hurdle model approach. Agribusiness, 24, 510-522. http://dx.doi.org/10.1002/agr.20176

\section{Copyrights}

Copyright for this article is retained by the author(s), with first publication rights granted to the journal.

This is an open-access article distributed under the terms and conditions of the Creative Commons Attribution license (http://creativecommons.org/licenses/by/3.0/). 